\title{
Cloned DNA Probes for Detection of Pseudomonas glumae Causing Bacterial Grain Rot of Rice
}

\author{
Seiya TSushima*, Chitoshi NARIMATSU**, \\ Akifumi MizUnO* and Ryosuke KIMURA*
}

\begin{abstract}
A 5.7-kilobase EcoRI fragment, PG2I, and a 3.9-kilobase EcoRI fragment, PG80I, were cloned randomly from the total DNA of Pseudomonas glumae, the causal agent of bacterial grain rot of rice. PG2I hybridized to all the 43 strains of $P$. glumae isolated from rice grain, rice seedlings, rice leaf sheaths and mung bean sprouts from different places, but PG80I did not hybridize to 5 of the 43 strains. PG2I seemed specific to this pathogen because this fragment failed to hybridize to selected strains of gram negative bacteria including $P$. gladioli pv. gladioli, $P$. gladioli pv. allicola, $P$. caryohylli, $P$. plantarii, $P$. solanacearum, $P$. cepacia, $P$. avenae, $P$. cichorii, $P$. aenginosa, $P$. syringae pv. phaseolicola, $P$. syringae pv. syringae, $P$. viridiflava, $P$. marginalis pv. marginalis, Agrobacterium radiobacter, $A$. rhizogenes, $A$. tumefaciens, Erwinia ananas, E. carotovora subsp. carotovora, $E$. herbicola, $X$. campestris pv. campestris, and $X$. campestris pv. oryzae, and gram positive bacteria including Arthrobacter illicis, Clavibacter michiganensis subsp. michiganensis, $\mathrm{Cl}$. michiganensis subsp. sepedonicus, Cl. rathayi, Curtobacterium albidum, C. citreum, C. flaccumfaciens pv. flaccumfaciens, C. flaccumfaciens pv. oortii and Rhodococcus fasciens. When PG2I was separated into two fragments, PG2Ia and PG2Ib, by digestion with KpnI, PG2Ia hybridized to all the strains but PG2Ib did not hybridize to 18 of the 43 strains of $P$. glumae, indicating that PG2Ia is specific to this pathogen. Hybridization patterns of PG2Ib and PG80I to these strains showed that they were divided into 4 groups and that at least three groups were present in three localities in Oita Prefecture in 1984. These findings suggest allopatric differentiation of different strains of $P$. glumae. These probes are considered to be useful for the detection of $P$. glumae in ecologial studies.
\end{abstract}

(Received April 19, 1994)

Key words: specific probe, Pseudomonas glumae.

\section{INTRODUCTION}

Pseudomonas glumae Kurita and Tabei causes rice seedling rot in the nursery boxes and rice grain rot in paddy fields in Japan. Bacterial grain rot is, especially, a serious disease in the southern part of Japan because this pathogen causes serious yield loss. The bacteria exist on rice plants ${ }^{7,10,18,19)}$ during the growing season, and the bacteria on leaf sheaths play a major role as a source of inoculum for the disease development on panicles ${ }^{18}$. Diseased panicles, which occur just after heading, are important in the focal formation in the field ${ }^{16)}$. Although the bacterium can survive in rice grain stored at room temperature ${ }^{17)}$, little is known about its survival in soil and other environments during winter. Tsushima et $a l^{17)}$ could not detect this pathogen from the diseased rice grain left for three months in winter on the soil surface in a field using the selective medium, $\mathrm{S}-\mathrm{PG}^{20}$. This is ascribed to the assumption that in winter the pathogen exists in grain at a lower level than the detection limit (approximately $10^{3} \mathrm{cfu} / \mathrm{g}$ ).

* National Institute of Agro-Environmental Sciences, Tsukuba, Ibaraki 305, Japan

** Japan Tobacco Inc., Oyama, Tochigi 323, Japan日本たばこ産業株式会社 
The survival of this pathogen in soil and other environments in winter still remains unknown and is important in terms of epidemiology.

DNA probes have been developed in some pathogenic bacteria for detection, identification ${ }^{3,4,12-15,21)}$ and restriction fragment length polymorphism (RFLP) analysis ${ }^{2,6}$. DNA-DNA hybridization with probe is a more rapid, sensitive, and specific method than conventional ones for identification of pathogenic bacteria ${ }^{14,21)}$. In these reports, DNA encoding pathogenicity gene ${ }^{2,3,12,13)}$ or DNA selected randomly from chromosomal DNA ${ }^{4,5,14,15,21)}$ were used as probes.

In this paper, we describe the prerequisite step for detecting Pseudomonas glumae from environment, e.g., isolation of $P$. glumae specific DNA probe from total DNA, and concomitant results on genetic differentiation in this bacterium.

\section{MATERIALS AND METHODS}

Bacterial isolates and DNA extraction. Pseudomonas glumae strain Kyu 82-34-220) was used for constructing DNA library. P. glumae was cultured at $28^{\circ} \mathrm{C}$ in PPG broth or on PPGA plates ${ }^{9}$. Escherichia coli strain was grown at $37^{\circ} \mathrm{C}$ in LB medium ${ }^{8)}$. The bacteria used for hybridization test are listed in Table 1. Other bacteria were cultured at $25^{\circ} \mathrm{C}$ in PPG broth or on PPGA plates.

Total DNA was extracted from bacteria using the method of MINIPREP using CTAB/ $\mathrm{NaCl}(10 \%$ hexadecyltrimethyl ammonium bromide in $0.7 \mathrm{M} \mathrm{NaCl}$ ) solution ${ }^{1}$. For lysis of the gram positive bacteria, $5 \mu 1$ of lysozyme $(100 \mu \mathrm{g} / \mathrm{ml})$ were added to proteinase $\mathrm{K}(100 \mu \mathrm{g} / \mathrm{ml})$ in $0.5 \%$ SDS.

DNA cloning and probe preparation. Total DNA of P. glumae Kyu 82-34-2 was purified as above, and digested with EcoRI. Digested DNA fragments were ligated into EcoRI digested pUC18 by Ligation Kit (Takara Ltd.) and were used to transform competent cells of E. coil JM109 (Takara Ltd.). Trasformed $E$. coli JM109 cells were selected on LB plates containing $50 \mu \mathrm{g} / \mathrm{ml}$ ampicillin and cultured in $\mathrm{LB}$ at $37^{\circ} \mathrm{C}$ for $24 \mathrm{hr}$. Harvested cells were resuspended in $350 \mathrm{ml}$ of STET (8\% sucrose, $5 \%$ TritonX$100,50 \mathrm{mM}$ EDTA, $50 \mathrm{mM}$ Tris- $\mathrm{HCl} \mathrm{pH} 8.0)$, treated with lysozyme $(10 \mathrm{mg} / \mathrm{ml})$, and incubated in boiling water for $40 \mathrm{sec}$. They were then precipitated in isopropanol to obtain plasmid DNA containing $P$. glumae chromosomal DNA fragments.

For the selection of plasmid DNAs containing P. glumae specific DNA fragment, 81 of about 300 transformed cells were screened against $P$. glumae Kyu 82-34-2 and 3 strains of $P$. gladioli species; pv. gladioli (MAFF 301064, ICMP 3950) and pv. allicola (ICMP 2804) which have similar bacteriological characteristics to $P$. glumae. One $\mu$ l of plasmid DNA solution (approximately $20 \mathrm{ng}$ ) was blotted on Optiblot nylon membrane (International Biotechnologies, Inc.) and hybridized with total DNAs (1 $\mu \mathrm{g}$ each) from $P$. glumae and 3 strains of $P$. gladioli species which were labeled with $\left[\alpha{ }^{32} \mathrm{P}\right] \mathrm{dCTP}$ (specific activity, $>3,000 \mathrm{Ci} / \mathrm{mmol}$ ) using Multiprime DNA labeling system (Amersham International plc). Hybridization was carried out overnight at $68^{\circ} \mathrm{C}$ in hybridization buffer $(7 \%$ SDS, $1 \%$ bovine serum albumin and $1 \mathrm{mM}$ EDTA in $1 \mathrm{M}$ sodium phosphate buffer, $\mathrm{pH}$ 7.0). The membranes were washed three times for $30 \mathrm{~min}$ in washing buffer (1\% SDS, $0.1 \%$ bovine serum albumin and $1 \mathrm{mM}$ EDTA in $50 \mathrm{mM}$ sodium phosphate buffer, $\mathrm{pH} 7.0$ ) at $65^{\circ} \mathrm{C}$. Autoradiography was performed on Fuji X-ray films.

Dot blot hybridization with total DNA of other bacteria. Total DNA solutions $(1 \mu \mathrm{g} / \mu \mathrm{l})$ of $1 \mu \mathrm{l}$ each from bacteria listed in Table 1 were blotted on nylon membranes and hybridized with DNA fragments specific to P. glumae, PG2I and PG80I, which were separated on $0.7 \%$ agarose gel after digesting PG2 and PG80 with Eco RI, respectively, and purified by using Bandprep (Amersham International plc). PG2I was further digested with $K p n I$ to obtain fragments, PG2Ia and PG2Ib, and separated on agarose gel. These two fragments were tested for specificity to 43 strains of $P$. glumae by dot blot hybridization.

\section{RESULTS AND DISCUSSION}

Plasmid DNAs, pG2 and pG80, which hybridized to $P$. glumae Kyu 82-34-2 but not two strains of $P$. gladioli pv. gladioli (MAFF 301064 and ICMP 3950) or P. gladioli pv. allicola (ICMP 2804), were selected 
Table 1. Strains of bacteria studied ${ }^{\mathrm{a})}$

\begin{tabular}{|c|c|c|}
\hline Bacterium & Strain & Other designation \\
\hline Pseudomonas glumae & $\begin{array}{l}\text { MAFF } 301094,301095,301096,301098, \\
\text { MAFF } 301099,301169^{\mathrm{T}}, 301170,301171, \\
\text { MAFF } 301172,301386,301389,301441, \\
\text { MAFF 301682, 302382, 302383, 302384, } \\
\text { MAFF 302394, 302395, 302396, 302397, } \\
\text { MAFF 302421, 302422, 302423, 302437, } \\
\text { MAFF 302438, 302439, 302440, 302441, } \\
\text { MAFF 302442, 302443, 302444, 302445, } \\
\text { MAFF 302446, 302447, 302448, 302449, } \\
\text { MAFF 302450, 302453, 302463, 302553, } \\
\text { Kyu82-34-2, Kyu82-40-1, Kyu82-41-1 }\end{array}$ & \\
\hline P. aeruginosa & MAFF $302206^{\mathrm{T}}$ & ATCC $10145^{\mathrm{T}}$ \\
\hline P. avenae & $\begin{array}{l}\text { MAFF } 302183^{\mathrm{T}} \\
\text { MAFF } 301024,301027,301031,301036 \text {, } \\
\text { MAFF 301141, 301502, 301505, 301576, } \\
\text { MAFF } 301609\end{array}$ & NCPPB $1011^{\mathrm{T}}$ \\
\hline P. caryophylli & $\begin{array}{l}\text { ICMP } 512^{\mathrm{T}} \\
\text { MAFF } 301060\end{array}$ & \\
\hline P. cepacia & $\begin{array}{l}\text { MAFF } 302528 \\
\text { A1, PC-10, PC-20, ALQ8281, } 86130\end{array}$ & \\
\hline P. cichorii & MAFF $301760,301761,301763$ & \\
\hline P. gladioli pv. gladioli & $\begin{array}{l}\text { ICMP } 3950^{\mathrm{T}} \\
\text { MAFF } 301064,301580,301584,301586 \text {, } \\
\text { MAFF } 301588,301728,302385,302537 \text {, } \\
\text { MAFF } 302543\end{array}$ & \\
\hline P. gladioli pv. allicola & ICMP $2804^{\mathrm{T}}$ & \\
\hline P. marginalis pv. marginalis & $\begin{array}{l}\text { MAFF 302031, 302032, 302033, 302036, } \\
\text { MAFF 302038, 302041, 302042, 302045, } \\
\text { MAFF 302046, 302047, 302048 }\end{array}$ & \\
\hline P. plantarii & MAFF $302381,302392,302479$ & \\
\hline P. solanacearum & $\begin{array}{l}\text { MAFF } 302154^{\mathrm{T}} \\
\text { MAFF } 301559,301492,301860,301067 \\
\text { MAFF } 301418,301524,301556\end{array}$ & ATCC $11696^{\mathrm{T}}$ \\
\hline P. syringae pv. phaseolicola & MAFF 301766 & \\
\hline$P$. syringae pv. syringae & $\begin{array}{l}\text { MAFF } 302155^{\mathrm{T}} \\
\text { MAFF } 301861,301862,301863,301864\end{array}$ & ATCC $19310^{\mathrm{T}}$ \\
\hline P. viridiflava & $\begin{array}{l}\text { MAFF } 301794,301795,301796,301798, \\
\text { MAFF } 301799,301800,301801,301802, \\
\text { MAFF } 301805\end{array}$ & \\
\hline Agrobacterium radiobacter & MAFF $302163^{\mathrm{T}}$ & ATCC $19358^{\mathrm{T}}$ \\
\hline A. rhizogenes & MAFF $302164^{\mathrm{T}}$ & ATCC $11325^{\mathrm{T}}$ \\
\hline A. tumefaciens & MAFF $302165^{\mathrm{T}}$ & ATCC $23308^{\mathrm{T}}$ \\
\hline Erwinia ananas & MAFF $302184^{\mathrm{T}}$ & NCPPB $1846^{\mathrm{T}}$ \\
\hline E. carotovora subsp. carotovora & MAFF $302159^{\mathrm{T}}$ & ATCC $15713^{\mathrm{T}}$ \\
\hline E. herbicola & MAFF $302186^{\mathrm{T}}$ & NCPPB $2971^{\mathrm{T}}$ \\
\hline Xanthomonas campestris pv. campestris & MAFF 301443 & \\
\hline$X$. campestris pv. oryzae & $\begin{array}{l}\text { MAFF } 301082,301083,301084,301085 \text {, } \\
\text { MAFF } 301086,301225,301226,301227\end{array}$ & \\
\hline Arthrobacter ilicis & MAFF $302180^{\mathrm{T}}$ & ATCC $14264^{\mathrm{T}}$ \\
\hline Clavibacter michiganensis subsp. michiga & $\begin{array}{l}\text { MAFF } 302187^{\mathrm{T}} \\
\mathrm{K} 1-1, \mathrm{R}-1\end{array}$ & NCPPB $2979^{\mathrm{T}}$ \\
\hline Cl. michiganensis subsp. sepedonicus & MAFF $302162^{\mathrm{T}}$ & $\operatorname{ATCC} 33113^{\mathrm{T}}$ \\
\hline
\end{tabular}




\section{Cl. rathayi}

Curtobacterium albidum

C. citreum

C. flaccumfaciens pv. flaccumfaciens

C. flaccumfaciens pv. oortii
MAFF $302197^{\mathrm{T}}$

MAFF 302648

MAFF 302649

NCPPB 1751, 2344

ATCC 33802

$\mathrm{T}-4$

MAFF 301198

NCPPB 156
NCPPB $2980^{\mathrm{T}}$

IFO 15078

IFO 12677

Rhodococcus fascians

a) ATCC; American Type Culture Collection.

ICMP ; International Collection of Micro-organisms from Plants.

IFO ; Institute for Fermentation OSAKA.

MAFF ; Ministry of Agriculture, Forestry and Fisheries of Japan.

NCPPB ; National Collection of Plant Pathogenic Bacteria.

Kyu82-34-2, 82-40-1, 82-41-1 ; S. Tsushima ${ }^{20)}$.

A1, PC-10, PC-20, ALQ8281, 86130 ; K. Tsuchiya, National Institute of Agrobiological Resources.

K1-1, R-1, T-4; T. Kobayashi, Yokohama Plant Protection Station.

Table 2. Dot blot hybridization of bacteiral strain probed with ${ }^{32} \mathrm{P}$-labeled PG2I and PG80I

\begin{tabular}{|c|c|c|c|}
\hline \multirow{2}{*}{ Bacterium } & \multirow{2}{*}{$\begin{array}{l}\text { Total no. of } \\
\text { strains tested }\end{array}$} & \multicolumn{2}{|c|}{ No. of strains hybridized to } \\
\hline & & PG2I & PG80I \\
\hline Pseudomonas glumae & 43 & 43 & 38 \\
\hline$P$. aeruginosa & 1 & 0 & $\mathrm{NT}^{\mathrm{a})}$ \\
\hline P. avenae & 10 & 0 & 0 \\
\hline P. caryophylli & 2 & 0 & 0 \\
\hline P. cepacia & 6 & 0 & 0 \\
\hline P. cichorii & 3 & 0 & NT \\
\hline P. gladioli pv. gladioli & 10 & 0 & 0 \\
\hline P. gladioli pv. allicola & 1 & 0 & 0 \\
\hline P. marginalis pv. marginalis & 11 & 0 & NT \\
\hline P. plantarii & 3 & 0 & 2 \\
\hline P. solanacearum & 8 & 0 & NT \\
\hline P. syringae pv. phaseolicola & 1 & 0 & NT \\
\hline P. syringae pv. syringae & 5 & 0 & NT \\
\hline P. viridiflava & 9 & 0 & NT \\
\hline Agrobacterium radiobacter & 1 & 0 & NT \\
\hline A. rhizogenes & 1 & 0 & NT \\
\hline A. tumefaciens & 1 & 0 & NT \\
\hline Erwinia ananas & 1 & 0 & NT \\
\hline E. carotovora subsp. carotovora & 1 & 0 & NT \\
\hline E. herbicola & 1 & 0 & NT \\
\hline Xanthomonas campestris pv. campestris & 1 & 0 & NT \\
\hline$X$. campestris pv. oryzae & 8 & 0 & NT \\
\hline Arthrobacter ilicis & 1 & 0 & NT \\
\hline $\begin{array}{l}\text { Clavibacter michiganensis } \\
\text { subsp. michiganensis }\end{array}$ & 3 & 0 & NT \\
\hline Cl. michiganensis subsp. sepedonicus & 1 & 0 & NT \\
\hline Cl. rathayi & 1 & 0 & NT \\
\hline Curtobacterium albidum & 1 & 0 & NT \\
\hline C. citreum & 1 & 0 & $\mathrm{NT}$ \\
\hline C. flaccumfaciens pv. flaccumfaciens & 3 & 0 & $\mathrm{NT}$ \\
\hline C. flaccumfaciens pv. oortii & 2 & 0 & NT \\
\hline Rhodococcus fascians & 1 & 0 & NT \\
\hline
\end{tabular}

a) NT; not tested. 
a

12345678910

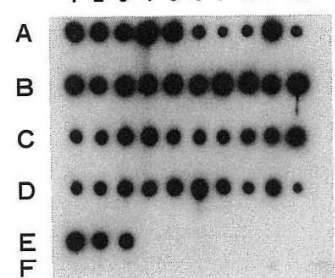

123345678910

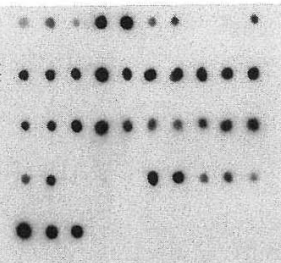

Fig. 1. DNA dot blot of 43 strains of Pseudomonas glumae and 10 strains of other bacteria probed with the insert DNA fragment, PG2I and PG80I, respectively. Probes, PG2I (a) and PG80I (b), were labeled with [ $\left.{ }^{32} \mathrm{P}\right] \mathrm{dCTP}$. Dots A (lanes 1 to 10 ), B (lanes 1 to 10 ), C (lanes 1 to 10 ), D (lanes 1 to 10 ) and $\mathrm{E}$ (lanes 1 to 3) represent $P$. glumae strains as following: A1, MAFF 301094; A2, MAFF 301095; A3, MAFF 301096; A4, MAFF 301098; A5, MAFF 301099; A6, MAFF 301169; A7, MAFF 301170; A8, MAFF 301171; A9, MAFF 301172; A10, MAFF 301386; B1, MAFF 301389; B2, MAFF 301441; B3, MAFF 301682; B4, MAFF 302382; B5, MAFF 302383; B6, MAFF 302384; B7, MAFF 302394; B8, MAFF 302395; B9, MAFF 302396; B10, MAFF 302397; C1, MAFF 302421; C2, MAFF 302422; C3, MAFF 302423; C4, MAFF 302437; C5, MAFF 302438; C6, MAFF 302439; C7, MAFF 302440; C8, MAFF 302441; C9, MAFF 302442; C10 MAFF 302443; D1, MAFF 302444; D2, MAFF 302445; D3, MAFF 302446; D4, MAFF 302447; D5, MAFF 302448; D6, MAFF 302449; D7, MAFF 302450; D8, MAFF 302453; D9, MAFF 302463; D10, MAFF 302553; E1, Kyu82-34-2; E2, Kyu82-40-1 and E3, Kyu82-41-1. E4 to E10; blank. Dots F (lanes 1 to 5 ) represent $P$. gladioli pv. gladioli strains as following; F1, MAFF 301064; F2, MAFF 301580; F3, MAFF 301584; F4, MAFF 301588 and F5, MAFF 302385. F (lanes 6 to 10) represent $P$. marginalis pv. marginalis as following: F5, MAFF 302031; F7, MAFF 302032; F8, MAFF 302033; F9, MAFF 302036 and F10, MAFF 302038.

from eighty one plasmids tested. Each insert DNA obtained from pG2 and pG80 was 5.7-kb and 3.9-kb long, respectively.

The 5.7-kb fragment, PG2I, hybridized specifically to all the 43 strains of $P$. glumae isolated from rice grain or seedlings collected from different places in Japan or mung bean sprouts but did not hybridize to $P$. gladioli pv. gladioli or $P$. gladioli pv. alicolla which was similar to $P$. glumae in bacterial charactericstics (Table 2). This fragment failed to hybridize to $P$. caryophylli, $P$. cepacia and $P$. solanacearum belonging to the rRNA homology group $\mathrm{II}^{11)}$ which included $P$. gladioli pv. gladioli and $P$. gladioli pv. alicolla. Furthermore, this fragment discriminated $P$. glumae from $P$. avenae and $P$. plantarii, the pathogens of rice seedlings (Fig. 1a and Fig. 2a). PG2I showed little homology not only with other gram negative bacteria but also with gram positive bacteria (Table 2). These results show that the fragment, PG2I is useful as a probe specific to $P$. glumae.

In contrast, the 3.9-kb fragment, PG80I did not hybridize to 5 of the 43 strains of $P$. glumae (Fig. 1b) and hybridized to 2 strains of $P$. plantarii, although this DNA failed to hybridize to other bacteria tested in the rRNA homology group II (Fig. 2b). These results indicate that the PG2I is more specific to $P$. glumae and is reliable for further tests against other bacteria.

The PG2I has a $K p n I$ site which divides this DNA into 2 fragments, PG2Ia (3.1 kb) and PG2Ib (2.6 kb) (Fig. 3). Specificity of these fragments to P. glumae was further examined. PG2Ia hybridized to all the 43 strains of $P$. glumae but PG2Ib did not hybridize to 18 strains (Fig. $4 \mathrm{a}$ and $4 \mathrm{~b}$ ), indicating that PG2Ia is more specific to this pathogen than PG2Ib.

The strains of $P$. glumae were divided into 4 groups by the patterns of hybridization with PG2Ib and PG80I probes (Table 3). PG2Ib and PG80I hybridized to 13 and 14 of the 14 strains isolated from rice seedlings, respectively, and to all the 4 strains from mung bean sprouts, but failed to hybridize to 16 and 5 of the 24 strains from rice grain, respectively. In the case of strains from grains, even though they were obtained from the same prefecture in the same year, i.e. Oita in 1984, hybridization patterns of each strain differred from locality to locality, indicating that the strains isolated from Yamaga, Azimu and Innai in Oita Prefecture differ genetically from each other and at least three groups defined by the 


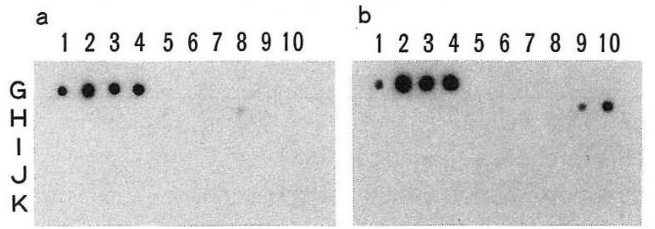

Fig. 2. DNA dot blot of 4 strains of Pseudomonas glumae and 42 strains of other bacteria probed with the insert DNA fragment, PG2I and PG80I, respectively. Probes, PG2I (A) and PG80I (B), were labeled with [ $\left.{ }^{32} \mathrm{P}\right]$ dCTP. Dots G (lanes 1 to 4 ) represent $P$. glumae strains as following: G1, MAFF 301169; G2, Kyu82-34-2; G3, Kyu82-40-1; G4, Kyu82-41-1. Dots G (lanes 5 to 10) and H (lanes 1 to 4) represent $P$. gladioli pv. gladioli strains and H (lane 5) represent $P$. gladioli pv. allicola strain as following: G5, MAFF 301064; G6, MAFF 301580; G7, MAFF 301584; G8, MAFF 301586; G9, MAFF 301588; G10, MAFF 301728; H1, MAFF 302385; H2, MAFF 302537; H3, MAFF 302543; H4, MAFF 302804 and H5, MAFF 303950. Dots H (lanes 6 and 7) represent $P$. caryophlli strains as following: H6, ICMP 512 and H7, MAFF 301060. Dots H (lanes 8 to 10) represent $P$. plantarii strains as following: H8, MAFF 302381; H9, MAFF 302392 and H10, MAFF 302479. Dots I (lanes 1 to 2 and 5 to 10) represent $P$. solanacearum strains as following: I1, MAFF 302154; I2, MAFF 301559; I5 MAFF 301492; I6, MAFF 301860; I7, MAFF 301067; I8, MAFF 301418; I9, MAFF 301524 and I10, MAFF 301556. I3 and I4, blank. Dots J (lanes 1 to 6) represent $P$. cepacia strains as following: J1, MAFF 302528; J2, A1; J3, PC-10; J4, PC-20; J5, ALQ8281 and J6, 86130. Dots J (lanes 7 to 10) and K (lanes 1 to 6) represent $P$. avenae strains as follows: J7, MAFF 302183; J8, MAFF 301024; J9, MAFF 301027; J10, MAFF 301031; K1, MAFF 301036; K2, MAFF 301141; K3, MAFF 301502; K4, MAFF 301505; K5, MAFF 301576 and K6, MAFF 301609.

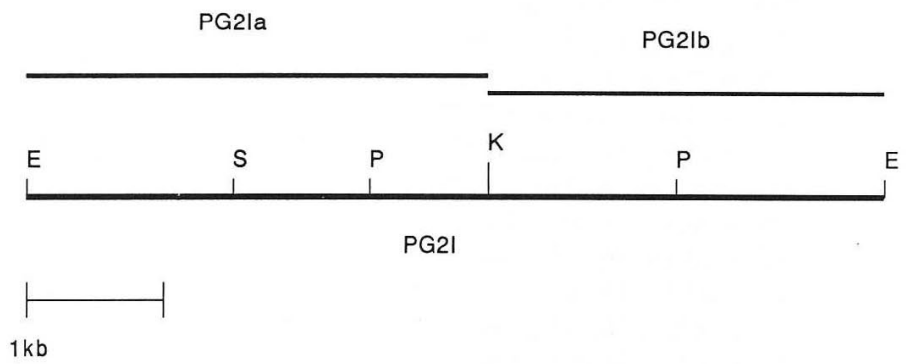

Fig. 3. Restriction map of a DNA fragment, PG2I. E, EcoRI; S, SacI; P, PstI and K, KpnI.

a b

$123456678910 \quad 12345678910$

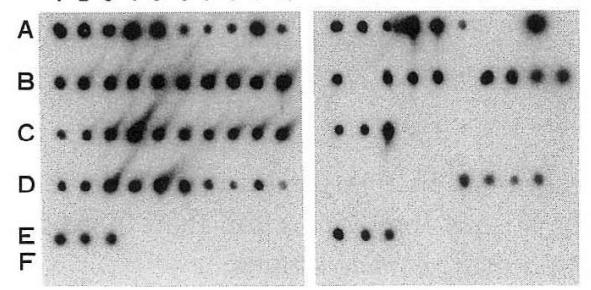

Fig. 4. DNA dot blot of 43 strains of Pseudomonas glumae and 10 strains of other bacteria probed with the KpnI-digested insert DNA fragment, PG2Ia and PG2I. Probes, PG2Ia (a) and PG2Ib (b), were labeled with $\left[{ }^{32} \mathrm{P}\right]$ dCTP. Each designation, see Fig. 1. 
Table 3. Hybridization of PG2Ia, PG21b and PG80I to isolates of Pseudomonas glumae ${ }^{\text {a) }}$

\begin{tabular}{|c|c|c|c|c|c|}
\hline & \multirow{2}{*}{ No. of strain } & \multirow{2}{*}{ Source } & \multicolumn{2}{|c|}{ PG2I } & \multirow{2}{*}{ PG80I } \\
\hline & & & PG2Ia & PG2Ib & \\
\hline \multirow[t]{24}{*}{ A) } & MAFF 301171 & rice grain, Kagawa, 1967 & + & - & - \\
\hline & MAFF 302446 & rice grain, Oita (Yamaga), 1984 & + & - & - \\
\hline & MAFF 302447 & rice grain, Oita (Yamaga), 1984 & + & - & - \\
\hline & MAFF 302448 & rice grain, Oita (Yamaga), 1984 & + & - & - \\
\hline & MAFF 301170 & rice grain, Nagasaki, 1967 & + & - & + \\
\hline & MAFF 301386 & rice grain, Fukuoka, 1973 & + & - & + \\
\hline & MAFF 301441 & rice grain, Hiroshima, 1982 & + & - & + \\
\hline & MAFF 302437 & rice grain, Oita (Azimu), 1984 & + & - & + \\
\hline & MAFF 302438 & rice grain, Oita (Azimu), 1984 & + & - & + \\
\hline & MAFF 302439 & rice grain, Oita (Azimu), 1984 & + & - & + \\
\hline & MAFF 302440 & rice grain, Oita (Azimu), 1984 & + & - & + \\
\hline & MAFF 302441 & rice grain, Oita (Azimu), 1984 & + & - & + \\
\hline & MAFF 302442 & rice grain, Oita (Azimu), 1984 & + & - & + \\
\hline & MAFF 302443 & rice grain, Oita (Azimu), 1984 & + & - & + \\
\hline & MAFF 302444 & rice grain, Oita (Azimu), 1984 & + & - & + \\
\hline & MAFF 302445 & rice grain, Oita (Azimu), 1984 & + & - & + \\
\hline & MAFF 301172 & rice grain, Shizuoka, 1967 & + & + & - \\
\hline & MAFF 301169 & rice grain, Ehime, 1967 & + & + & + \\
\hline & MAFF 302449 & rice grain, Oita (Innai), 1984 & + & + & + \\
\hline & MAFF 302450 & rice grain, Oita (Innai), 1984 & + & + & + \\
\hline & MAFF 302453 & rice grain, Oita (Innai), 1984 & + & + & + \\
\hline & Kyu82-34-2 & rice grain, Fukuoka, 1982 & + & + & + \\
\hline & Kyu82-40-1 & rice grain, Fukuoka, 1982 & + & + & + \\
\hline & Kyu82-41-1 & rice grain, Fukuoka, 1982 & + & + & + \\
\hline B) & MAFF 302553 & rice leaf sheath, Kumamoto, 1984 & + & - & + \\
\hline \multirow[t]{14}{*}{ C) } & MAFF 301094 & rice seedling, Okayama, 1975 & + & + & + \\
\hline & MAFF 301095 & rice seedling, Okayama, 1975 & + & + & + \\
\hline & MAFF 301096 & rice seedling, Okayama, 1975 & + & + & + \\
\hline & MAFF 301098 & rice seedling, Okayama, 1975 & + & + & + \\
\hline & MAFF 301099 & rice seedling, Okayama, 1975 & + & + & + \\
\hline & MAFF 301389 & rice seedling, Akita, 1979 & + & + & + \\
\hline & MAFF 301682 & rice seedling, Ibaraki, 1982 & + & + & + \\
\hline & MAFF 302382 & rice seedling, Ibaraki, 1982 & + & + & + \\
\hline & MAFF 302383 & rice seedling, Ibaraki, 1982 & + & + & + \\
\hline & MAFF 302384 & rice seedling, Ibaraki, 1982 & + & - & + \\
\hline & MAFF 302394 & rice seedling, Miyagi, 1983 & + & + & + \\
\hline & MAFF 302395 & rice seedling, Miyagi, 1983 & + & + & + \\
\hline & MAFF 302396 & rice seedling, Miyagi, 1983 & + & + & + \\
\hline & MAFF 302397 & rice seedling, Miyagi, 1983 & + & + & + \\
\hline \multirow[t]{4}{*}{ D) } & MAFF 302421 & Mung bean sprouts, Ibaraki, 1984 & + & + & + \\
\hline & MAFF 302422 & Mung bean sprouts, Ibaraki, 1984 & + & + & + \\
\hline & MAFF 302423 & Mung bean sprouts, Ibaraki, 1984 & + & + & + \\
\hline & MAFF 302463 & Mung bean sprouts, Ibaraki, 1984 & + & + & + \\
\hline
\end{tabular}

a) Bacterial strains were isolated from rice grain $(A)$, rice leaf sheath $(B)$, rice seeddling $(C)$ and mung bean sprouts (D).

patterns of hybridization were present in this prefecture. These results suggest that hybridization patterns are more diverse in the strains from rice grain than those from seedlings and, furthermore, imply the allopatric differentiation of $P$. glumae strains.

This is the first report on a DNA probe specific to $P$. glumae. The fragment PG2I obtained in this experiment is applicable as a hybridization probe to detect this pathogen in environments. 
We thank Dr. Nishiyama for suggestions and providing us with bacterial isolates and Dr. Matsumoto for suggestions and critical reading of the manuscript.

\section{Literature cited}

1. Asubel, F.M., Brent, R., Kingstone, R.E., Moore, D.D., Seidman, J.G. and Smith, J.A. (1988). Current Protocols in Molecular Biology. John Wiley \& Sons, New York.

2. Boccara, M., Vedel R., Lalo, D., Lebrun, M. and Lafay, J.F. (1991). Genetic diversity and host range in strains of Erwinia chrysanthemi. Mol. Plant-Microbe Interact. 4 : 293-299.

3. Cupples, D.A., Moore, R.A. and Morris, V.L. (1990). Construction and use of a nonradioactive DNA hybridization probe for detection of Pseudomonas syringae pv. tomato on tomato plants. Appl. Environ. Microbiol. 56 : 1743-1749.

4. Denny, T.P. (1988). Differentiation of Pseudomonas syringae pv. tomato from P.s. syringae with a DNA hybridization probe. Phytopathology 78 : 1186-1192.

5. Leach, J.E., White, F.W., Rhoads, M.L. and Leung, H. (1990). A repetitive DNA sequence differentiates Xanthomonas campestris pv. oryzae from other pathovars of Xanthomonas campestris. Mol. Plant-Microbe Interact. $3: 238-246$.

6. Leach, J.E., Rhoad, M.L., Vera Cruz, C.M., White, F.F., Mew, T.W. and Leung, H. (1992). Assessment of genetic diversity and population structure of Xanthomonas oryzae pv. oryzae with a repetitive DNA element. Appl. Environ. Microbiol. 58 : 2188-2195.

7. Matsuda, I. and Sato, Z. (1987). Ecology of P. glumae, cause bacterial grain rot of rice, from planting to the mature stage. Ann. Phytopath. Soc. Japan 53: 122 (Abstr. in Japanese).

8. Miller, J.H. (1972). Experiments in molecular genetics. Cold Spring Harbor Laboratory Press, Cold Spring Harbor, NY.

9. Nishiyama, K. (1978). Rapid identification method for plant pathogenic bacteria. Shokubutu boeki (Plant Protection) $32: 283-288$ (in Japanese).

10. Otofuji, M., Kadoshige, K. and Yoshida, K. (1988). Persistent part of Pseudomonas glumae Kurita et Tabei in rice plant. Proc. Assoc. P1. Prot. Kyushu 34: 1-4 (in Japanese).

11. Palleroni, N.J. (1984). Family I. Pseudomonadeae Winsloe, Broadhurst, Buchanan Krumwiede, Rogers and Smith 1917, 555 AL In Bergey's Manual of Systematic Bacteriology, vol. I. (Krieg, N.R. and Holt, J.G. eds.). Williams \& Wilkins, Baltimore. pp. 141-219.

12. Prosen, D., Hatziloukas, E., Schaad, N.W. and Panopoulos, N.J. (1993). Specific detection of Pseudomonas syringae pv. phaseolicola DNA in bean seed by polymerase chain reaction-based amplification of a phaseolotoxin gene region. Phytopathology 83 : 965-970.

13. Schaad, N.W., Azad, H., Peet, R.C. and Panopoulos, N.J. (1989). Indentification of Pseudomonas syringae pv. phaseoleiocola by a DNA probe. Phytopathology 79: 903-907.

14. Seal, S.E., Jackson, L.A. and Daniels, M. (1992). Isolation of a Pseudomonas solanacearum-specific DNA probe by subtraction hybridization and construction of species-specific oligonucleotide primers for sensitive detection by the polymerase chain reaction. Appl. Environ. Microbiol. 58: 3751-3758.

15. Thompson, E., Leary, J.V. and Chun, W.W.C. (1989). Specific detection of Clavibacter michiganense subsp. michiganense by a homologous DNA probe. Phytopathology 79 : 311-314.

16. Tsushima, S. and Naito, H. (1991). Spatial distribution and dissemination of bacterial grain rot of rice caused by Pseudomonas glumae. Ann. Phytopath. Soc. Japan $57: 180-187$.

17. Tsushima, S., Mogi, S., Naito, H. and Saito, H. (1989). Existence of Pseudomonas glumae on the rice seeds and development of the simple method for detecting P. glumae from the rice seeds. Bull. Kyushu Natl. Agric. Exp. Stn. 25 : 261-270 (in Japanese).

18. Tsushima, S., Mogi, S., Naito, H. and Saito, H. (1991). Populations of Pseudomonas glumae on rice plants. Ann. Phytopath. Soc. Japan 57 : 145-152.

19. Tsushima, S., Tsuno, K., Mogi, S., Wakimoto, S. and Saito, H. (1987). The multiplication of Pseudomonas glumae on rice grains. Ann. Phytopath. Soc. Japan 53 : 663-667 (in Japanese).

20. Tsushima, S., Wakimoto, S. and Mogi, S. (1986). Selective medium for detecting Pseudomonas glumae Kurita et Tabei, the causal bacterium of grain rot of rice. Ann. Phytopath. Soc. Japan 52: 253-259 (in Japanese).

21. Ward, L.J. and Boer, S.H. (1990). A DNA probe specific for serologically diverse strain of Erwinia carotovora. Phytopathology $80: 665-669$. 


\section{和 文 摘 要}

対馬誠也・成松千寿・水野明文・木村龍介：イネもみ枯細菌病菌検出のためのDNAプローブ

イネもみ枯細菌病菌 (Pseudomonas glumae) Kyu 82-34-2 から, ショットガンクローニングにより, DNA 断片 PG 2 I $(5.7 \mathrm{~kb}), \mathrm{PG} 80 \mathrm{I}(3.9 \mathrm{~kb})$ を得た。PG 2 I はドットブロットハイブリダイゼーションにより供試した本種の 43 菌株 全てに高い相同性を示したが, 他の 25 種 99 菌株にはほとんど反応しなかった。一方, PG 80 I は P. glumae 43 菌株中 5 菌株には反応せず，かつ P. plantarii 3 菌株中 2 菌株に高い相同性を示したことから, PG 2 I が P. glumae により特 異的であると考えた。そこで, PG 2 I を制限酵素 KpnI により 2 つの断片（PG 2 Ia，PG 2 Ib) に分割し，P.glumae に対する特異性を調べた結果, PG 2 Ia (3.1 kb) が供試した全菌株に高い相同性を示し, P. glumae の特異的プローブ として有効であると考えた。PG 2 Ia, PG 2 Ib および PG 80 I に対する P. glumae 各菌株のハイブリダイゼーションの パターンから, 供試菌株は䉽由来の菌株で 4 群, イネ幼苗由来の菌株で 2 群, また緑豆のもやし由来の菌株で 1 群に分 かれた。さらに, 同一県内でも地区毎にハイブリダイゼーションのパターンが異なる菌株が分布していることが示唆さ れた。 